医器学 Vol. 53, Suppl. (1983)

回 答

\section{広島大第 1 外科 福 永 信 太 郎}

収縮と㹡張を切り換えるので，電磁弁のON-
OFF のみで十分と考える. Filling point と empty point によって Starling の法則に従っ て制御しているので心拍数は自動的に変化す る.

\title{
29. 開心術中の体外循環における安全装置の開発
}

—リザーバ血液レベルセンサおよび

$$
\text { コラプスモニタの試作—— }
$$

福井康裕 ${ }^{*}$ 別府俊幸* 小林 昭* 土屋喜一*2 今井康晴*3 高梨吉則*3 副島健市*3 石原和 明*3

\section{1.はじめに}

開心術中の体外循環において人工心肺操作者 は，生体の状態の変化に応じて適切な灌流操作 を行わなければならず，その操作には細心の注 意が必要である。今日，開心術症例は複雑化の 傾向にあり，灌流操作も長時間化し，操作者に かかる負担は増加することが予想される。した がってヒューマンエラー発生の確率す高くなる ものと思われる。

このような複雑な操作を必要とする状況にお いてのヒューマンエラーを防ぎ，より安定した 灌流量の制御を目的として，われわれはマイク ロコンピュータによる自動制御機能を有する人 工心肺装置の開発を進めている1)、今回，本シ ステムにおけるフェイルセーフ機構の1つとし てリザーバ血液レベルセンサおよびコラプスモ ニタを試作したので報告する.

\section{2. 方 法}

われわれの体外循環実験のシステムを図 1 に 示す．血液回路は送脱血ポンプ，人工肺，リザ 一バにより構成され，送脱血流量はコンピュー タにより自動制御される。

コラプスモニタは脱血カニューレより脱血ポ ンプに至る血液回路中に，また，リザーバ血液

* 東京電機大学理工学部

*2 早稲田大学理工学部

*3 東京女子医科大学心研外科

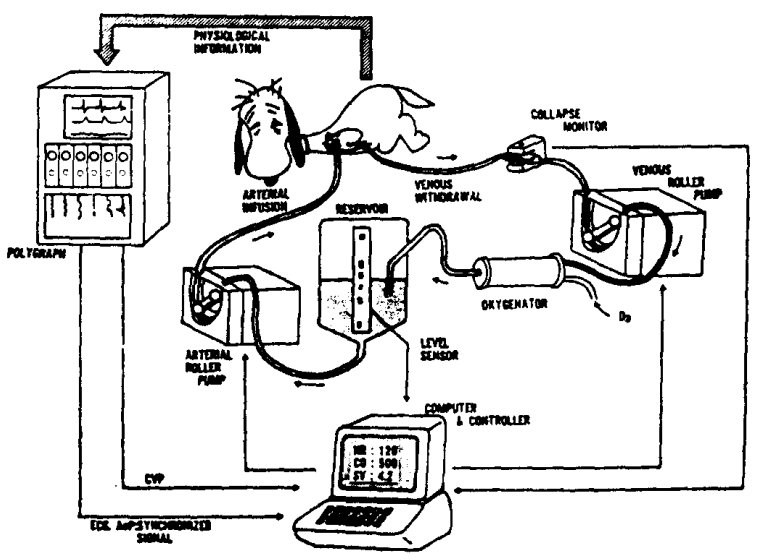

图 1 マイクロコンピュータ自動制御による 人エ心肺システム

レベルセンサはリザーバ部に設ける。これらの センサからの情報は，コンピュータに入力され るが，センサ単体でも使用可能となっている。

2-1. リザーバ血液レベルセンサ

リザーバ血液レペルセンサとしては従来より 重量バランス式 ${ }^{2)}$ ，超音波センス式などの検出 万法があるが，使用できるリザーバが限られて しまら，正確なレベルセンスが困難であるなど の問題点があり，満足のできる性能ではなかっ た.

試作したリザーバ血液レベルセンサの原理を 図 2 に示す.レベルセンサには光センサを用い る. 光センサを用いた理由としては，非接触方 式であるため清潔を保てる，電気的に安全であ る, 電気メスなどの電磁的ノイズから逃れるこ 


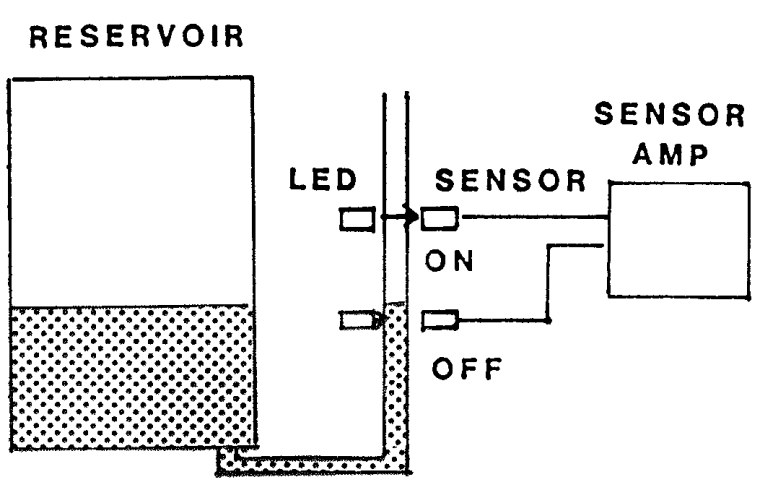

图 2 リザーバレベルセンサ原理

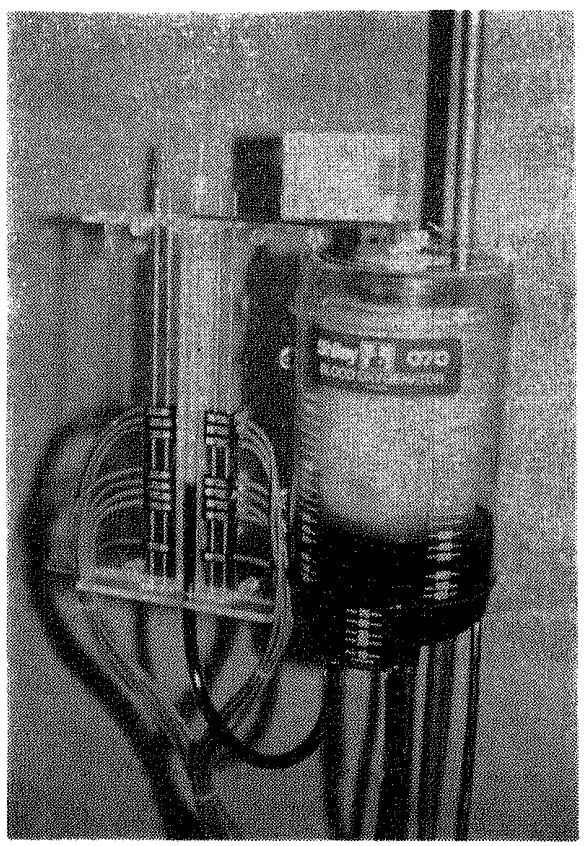

図 3 リザーパ血液レベルセンサ

とができる，などが挙げられる，また外部光の 影響を防ぐため光センサには変調光式のタイプ を使用する。

リザーバ血液レベルセンサは，リザーバ底面 より $\mathrm{J}$ 字状の血液誘導回路を作り，この回路を 挾んで 8 組のセンサを配置する，そして一方か ら出た光が他方に透過するか否かで血液の有無 を判定する（図 3 ).

これらのセンサから得られる情報は，外部の モニタに出力されるとともに，フェイルセーフ 機構として血液レベルが下から 2 番目のセンサ 以下になった場合は警報音を発生し，人工心肺 操作者に貯血レベルの低下を知らせ，さらに血 液レベルが最下位のセンサ以下になった場合に は，空気を送り込むことのないように，送血ポ

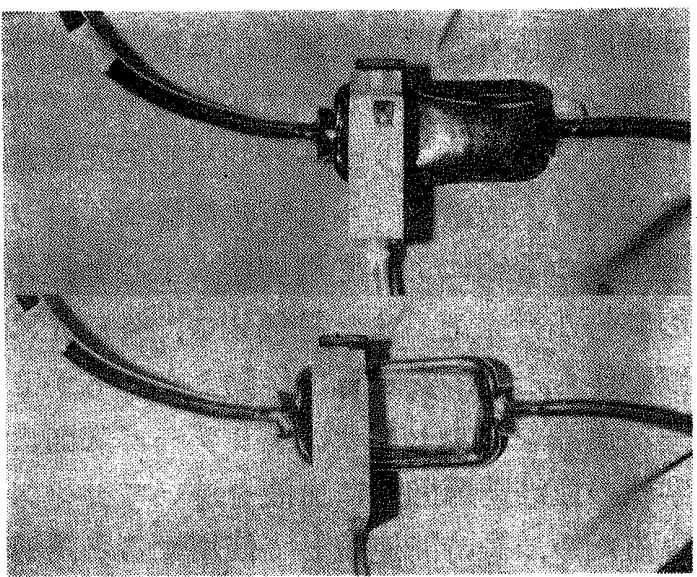

図 4 コラプスセンサ

上：通常状照 下: コラプス状䅧

SENSOR

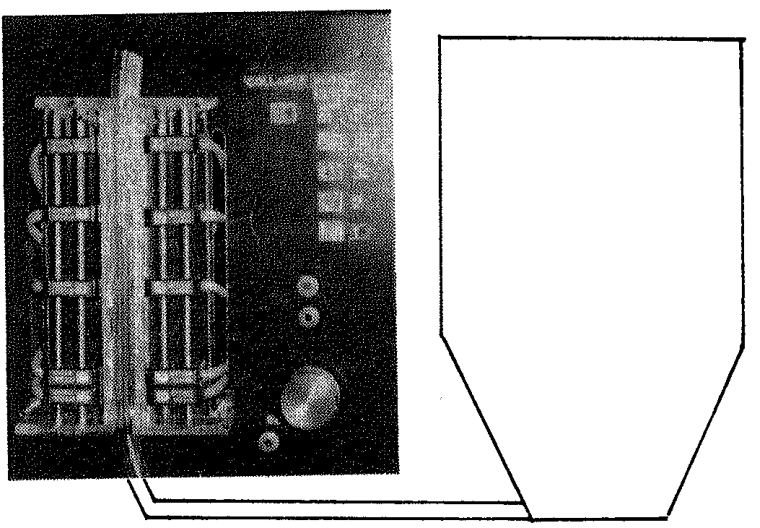

図 5 リザーパレペルセンサ 2 号機

ンプを停止させる.

\section{2-2. コラプスモニタ}

ポンプを使い強制的に脱血する場合には血液 回路中にエアレスバッグを接続し，エアレスバ ッグがつぶれることによって脱血過多を認識す る. しかし人工心肺操作者がコラプス状態に気 づかずに灌流操作を続けることもあるため,こ の場合のフェイルセーフ機構として、コラプス 状態を警報音によって認識させるコラプスモニ タを試作した（図 4 ）。

コラプスモニタもリザーバ血液レベルセンサ と同様に光センサを用い，エアレスバッグのつ ぶれを検出する。

\section{3. 実 験}

本リザーバ血液レベルセンサおよびュラプス モニタを動物実験に使用した，実験は図 1 に示 すシステムで雑種幼犬（8１0 kg）を用い，2 
医器学 Vol. 53, Suppl. (1983)

〜 3 時間の体外循環を実施し，この間のリザー バ血液レベルおよびコラプス状態をモニタリン グする，その結果，リザーバレベルの正確なモ ニタリング, 血液レベル低下時の警報、 コラプ ス発生時の警報によって適切な人工心肺操作者 への警告が行えた。また電気メス，外部光によ る誤動作もなく，安定して作動した。しかしり ザーバ血液レベルセンサは，リザーバ底面より J 字状の血液誘導回路に血液を導いてセンスし ているため, 長時間連続して使用すると誘導回 路中の血球が沈み，正確なセンスができなくな ることがあった：この塲合，血液誘導回路内を フラッシュすることによって再び正確にセンス できるようにした。

\section{4.まとめ}

動物実験を通して, 本りザーバ血液レベルセ ンサおよびコラプスモニタの有効性を確認し た．そこで実際に臨床に使用するための 2 号機
を製作している（図 5)。

2 号機も 1 号機と同じく，七ンサと警報音発 生器を組み合わせたフェイルセーフ機構として いる.これも血液レベル低下時には送血ポンプ 停止信号を出力し，これをトノクラ製人工心肺 装置を改造して入力し, 送血ポンプを停止させ ることを可能にしている．2 号機は近日中に臨 床使用の予定である.

\section{文献}

1）福井康裕他：乳児用人工心肺装置 の研究 第 4 報, 人工臟器 ' $82 / 6, \quad \mathrm{P} 1232 \sim 5$.

2) 川島康生他 : 体外循環 P $36 \sim 7$. 日本人工臟器 学会.

（本研究の一部は文部省科学研究費、試験研究を用 いて行った）

\section{0.ポリプロピレン・ホローファイバ人工肺安応用 した体外循環時の血液粘度連続監視の開発}

$\begin{array}{lll}\text { 过 隆 之* } & \text { 戸川達男* } & \text { 田村俊世* } \\ \text { 豊島 健* } & \text { 根本 鉄* 成 味 純*2 } \\ \text { 金子秀実 } & \text { 須磨幸蔵 }{ }^{* 2} \text { 福井康 裕*3 }\end{array}$

はじめに

ポリプロピレン・ホローファイバ人工肺内に おける血液の流れを検討し, 流量と圧力損失の 関係から流体粘度を推定する力法を実験的に検 討した。

\section{1. 対象ならびに方法}

図 1 , 表 1 のよな熱交換器つきのポリプロ ピレン・ホローファイバ人工肺を対象とした。 本人工肺を用い，図 2 のような回路を作製し人 工肺を水平に設置した。 ローラポンプ(Pemco)

* 東京医科歯科大学医用器材研究所

*2 東京女子医科大学第 2 病院

*3 東京電機大学理工学部
で回路に水を流し，10〜60回転まで回転数を， また 0 450 mmHg まで後負荷をかえて流量 と回転数の関係を校正した。

1) 水温を $10 \sim 35^{\circ} \mathrm{C}$ まで $5^{\circ} \mathrm{C}$ ごとに変 化させ，各水温ごとに流量を 6 段階（10６0 $\mathrm{rpm}$ ) に変化させた。 その時の流量と人工肺前 後の圧力損失の関係を検討した。

2 ) 各水温時の水の既知の粘度 $\eta$ (理科年表, p. 物 27）と 1）の圧流量関係を検討した。 さ らにホローファイバによってのみ圧力損失がも たらされたと仮定して，ハーゲン・ポワゼイュ の式から粘度を算定した。

3）体外循環後のヒト血液（Ht 18\%）を用 